профессионализм и создание всегда творческой атмосферы.

Татьяна Занько, Полина Золина, Ольга Бергер

https://doi.org/10.5817/NR2019-2-10

\section{Světové setkání rusistů - XIV. mezinárodní kongres MAPRJAL v Kazachstánu}

Ve dnech 30. 4. - 3. 5. 2019 probíhal v hlavním městě Kazachstánu Nur Sultanu (dřive Astana) XIV. mezinárodní kongres MAPRJALu (Mezinárodní asociace učitelů ruského jazyka a literatury), jemuž dominovalo ústřední téma Russkoe slovo $v$ mnogojazyčnom mire. Setkání se účastnili nejen středoškolští a vysokoškolští učitele ruského jazyka, literatury a kultury, ale i slavisticky orientovaní filologové, kteří společně jednali na Euroasijské národní univerzitě L. N. Gumileva. Na čtrnácti tematických sekcích a šesti kulatých stolech participovalo zhruba 800 rusistů z 47 zemí (oficiální počty uváděné pořadateli se v tomto ohledu lišily), kteří posuzovali tradiční badatelské okruhy jak spjaté s otázkami jazykové výuky, bilingvismu a fungování ruštiny v současném světě, tak i ryze vědecká témata $\mathrm{z}$ oblasti translatologie, mezikulturní komunikace, frazeologie, lexikografie, sociolingvistiky, literární vědy, kulturologie apod.
Objevily se i širší přesahy směrem ke kulturní politice prosazované Ruskou federací jako export ruštiny chápaný ve smyslu sjednocujícího elementu mírové zahraniční politiky a moderní výchovy a vzdělání. Třeba však zdơraznit, že drtivá většina přednesených referátů objektivně reflektovala dosažené výsledky vědy a výuky ruštiny $\mathrm{v}$ jednotlivých zemích např. $v$ podobě přehledu publikací, konferencí a projektů. Tím i pouhá výměna informací včetně seznámení se $s$ někdy nedostupnými bibliografiemi (např. z bývalých teritorií tehdejšího Sovětského svazu) překračovala heuristická očekávání badatelsky naladěných účastníků. Úvodních šest referátů s panelovou diskusí, které včetně slavnostního zakončení a závěrečného plenárního zasedání zazněly v aule luxusního hotelu Ritz-Carlton, přednesli L. A. Verbická (Rusko), E. D. Sulejmenova (Kazachstán), D. Davidson (USA), V.I. Šulženko (Rusko), A. Mustajoki (Finsko) a S. A. Kuzněcov (Rusko). Tematika zde byla proměnlivá: od oficiální jazykové politiky a její úlohy ve slovanském a neslovanském světě, přes otázky spisovnosti a státních jazykových standardů, transformativních metod výuky cizím jazykům až ke kulturnímu odkazu ruské klasické literatury na čele s Puškinem, k úvahám o současné, rusky psané literatuře vznikající doma i v zahraničí.

MAPRJAL, na jehož vzniku se podíleli i čeští rusisté, byl založen v roce 1972 v Paříži a v současnosti sdružuje vyučující ruštiny zhruba ze 70 zemí. Jak uvedla ve svém referátu dosavadní prezidentka 
MAPRJALu a rektorka petrohradské univerzity Ludmila Verbická, ruština se španělštinou dělí o třetí a čtvrté místo podle územního rozšíření, přibližně 250 mil. lidí na nejrůznější úrovni tento jazyk komunikačně použivá, přičemž 160 mil. ji pokládá za svůj rodilý jazyk a 120 mil. za druhý jazyk. Je zajímavé, že v této statistice se Češi se Srby vyskytují na čtvrtém a pátém místě $\mathrm{v}$ absolutním pořadí ve znalosti ruštiny. Předpokládá se, že zhruba $20 \%$ obyvatel České republiky je schopno se dorozumět na běžné úrovni. Můžeme jen litovat, že za Českou republiku se tohoto vrcholného jednání účastnili pouze předseda České asociace rusistů Jiří Klapka a autor těchto řádků, který na vyžádání organizátorů prezentoval (i v zastoupení svého kolegy Tomáše Hermanna z Ústavu pro soudobé dějiny AV ČR a Př́rodovědecké fakulty UK v Praze) své jakobsonovské výzkumy za poslední období, zejména představil novou kritickou edici Jakobsonovy kontroverzní monografie Moudrost starých Čechů původně vydané za druhé světové války $\mathrm{v}$ USA. Jen pro ilustraci: slovenskou delegaci tvořily dvě desítky vědců a pedagogů $\mathrm{z}$ univerzit a středních škol, z nichž polovina si veškeré náklady entuziasticky hradila sama. Za úspěch české rusistiky však možno považovat fakt, že na závěrečném valném shromáždění byl Jiří Klapka jednomyslně zvolen již po čtvrté do mezinárodního prezidia, zatímco řada jiných kandidátů, mj. právě předsedkyně Slovenské asociace rusistů Eva Kollárová, neprošla. Ze zdravotních důvodů nekandidovala za prezidentku
MAPRJALu Ludmila Verbická, která stála v čele této organizace dvacet let. Její místo obsadil spisovatel a žurnalista Vladimír Iljič Tolstoj ( ${ }^{*}$ 1962), od roku 2012 poradce prezidenta Putina v otázkách ruského jazyka a prapravnuk klasika ruské literatury, který zároveň spravuje nadační fond svého světoznámého předka. Nepřekvapí proto, že za další místo konání XV. sjezdu v roce 2023 byl vybrán Petrohrad jako tradiční symbol ruské kultury.

Jestliže světové kongresy bývají $\mathrm{v}$ době internetové komunikace pro svou tematickou šíri někdy považovány za „monstrakce“, za jakousi trpěnou přehlídku „ztraceného času“, pro MAPRJAL za sovětské éry toto nebezpečí mohlo platit, záleželo však na každém badateli, co od tohoto kongresu očekával. V současnosti byl evidentní sympatický posun od didaktiky a empirických otázek výuky $\mathrm{k}$ vědě a interdisciplinárním projektům na hraně mezi filologií, dialogem kultur a areálovými studiemi. I v kuloárních rozhovorech se jako červená nit totiž prolínalo přaní, aby MAPRJAL nebyl vnímán jako prolongace povinného setkání filologicky zaměřených pedagogů, ale jako institucionální opora pro neideologický, synchronně-diachronní výzkum ruského jazyka a literatury v badatelské perspektivě. Je však zřejmé, že tato idea bude konfrontována s přirozenými vlivy a mocenskými zásahy slovanské velmoci, která si logicky chrání svou politickou, ekonomickou a také jazykově-kulturní integritu.

Miloš Zelenka 